\title{
Chronotype and work shift in nursing workers of university hospitals
}

\author{
Cronotipo e turno de trabalho em trabalhadores de enfermagem de hospitais universitários \\ Cronotipo y turno de trabajo en trabajadores de enfermería de hospitales universitarios
}

\section{Rosângela Marion da Silva', Regina Célia Gollner Zeitoune", Carmem Lúcia Colomé Beck', Milva Maria Figueiredo de Martino ${ }^{\mathrm{III}}$, Francine Cassol Prestes ${ }^{\mathrm{IV}}$, Marli Maria Loro}

' Universidade Federal de Santa Maria, Nursing Department. Santa Maria, Rio Grade do Sul, Brazil. "Universidade Federal do Rio de Janeiro, Anna Nery School of Nursing, Department of Public Health. Rio de Janeiro, Brazil.

II' Universidade Estadual de Campinas, School of Medical Sciences, Nursing Department. Campinas, São Paulo, Brazil.

IV Instituto Federal Farroupilha, Campus São Vicente do Sul. São Vicente do Sul, Rio Grande do Sul, Brazil.

${ }^{\vee}$ Universidade Regional do Noroeste do estado do Rio Grande do Sul, Department of Life Sciences. Ijuí, Rio Grande do Sul, Brazil.

\section{How to cite this article:}

Silva RM, Zeitoune RCG, Beck CLC, Martino MMF, Prestes FC, Loro MM. Chronotype and work shift in nursing workers of university hospitals. Rev Bras Enferm [Internet]. 2017;70(5):958-64. [Thematic Edition "Good practices and fundamentals of Nursing work in the construction of a democratic society"] DOI: http://dx.doi.org/10.1590/0034-7167-2016-0542

\section{Submission: 03-29-2016 Approval: 01-31-2017}

\section{ABSTRACT}

Objective: To identify the predominant chronotype in nursing workers who work in surgical clinics of university hospitals and to verify the association with work shift. Method: Cross-sectional study, performed in surgical clinics of university hospitals in the Southern region of Brazil. The sample of 270 nursing workers answered questions of socio-occupational characterization, of health and the Morningness-Eveningness Questionnaire of Horne and Östberg. We performed a descriptive and bivariate analysis with the help of the SPSS software and confidence interval of $95 \%$. Results: The indifferent chronotype predominated $(45.2 \%)$. There were significant differences between occupational categories and variables "age" $(p<0.001)$, "use of medication" $(p=0.035)$ and "choice of work shift" $(p=0.001)$. There was an association between the chronotype and the variables "work leave due to illness" ( $p=0.021)$, "children" $(p=0.025)$, "use of medication" ( $p=0.018)$ and "work shift" $(p=0.001)$. Conclusion: The chronotype remained indifferent, and the results confirmed association between chronotype and work shift.

Descriptores: Nursing; Occupational Health; Shift Work; Circadian Rhythm; Nursing Service, Hospital.

\section{RESUMO}

Objetivo: Identificar o cronotipo predominante em trabalhadores de enfermagem que atuam em clínicas cirúrgicas de hospitais universitários e verificar associação com o turno de trabalho. Método: Estudo transversal, realizado em clínicas cirúrgicas de hospitais universitários da região Sul do Brasil. A amostra de 270 trabalhadores de enfermagem respondeu questões de caracterização sociolaboral, de saúde e o Questionário de Matutinidade-Vespertinidade de Horne e Östberg. Realizou-se análise descritiva e bivariada com auxílio do software SPSS e intervalo de confiança de $95 \%$. Resultados: Predominou o cronotipo indiferente $(45,2 \%)$. Houve diferença significativa entre as categorias profissionais e as variáveis "idade" $(p<0,001)$, "uso de medicação" $(p=0,035)$ e "opção pelo turno de trabalho" ( $p=0,001)$. Foi identificada associação entre o cronotipo e as variáveis "afastado do trabalho por motivo de doença" ( $p=0,021)$, "filho(s)" ( $p=0,025)$, "uso de medicação" $(p=0,018)$ e "turno de trabalho" $(p=0,001)$. Conclusão: Predominou o cronotipo indiferente, e os resultados confirmaram a associação entre cronotipo e turno de trabalho.

Descritores: Enfermagem; Saúde do Trabalhador; Trabalho em Turnos; Ritmo Circadiano; Serviço Hospitalar de Enfermagem.

\section{RESUMEN}

Objetivo: Identificar el cronotipo predominante en trabajadores de enfermería que actúan en clínicas quirúrgicas de hospitales universitarios y verificar asociación con el turno de trabajo. Método: Estudio transversal realizado en clínicas quirúrgicas de hospitales universitarios de la región sur de Brasil. La muestra de 270 trabajadores de enfermería respondió cuestiones de caracterización sociolaboral, de salud y el Cuestionario de Matutinidad-Vespertinidad de Horne y Östberg. Se realizó un análisis descriptivo y bivariado con ayuda del software SPSS y un intervalo de confianza del 95\%. Resultados: Predominó el cronotipo intermedio (45,2\%). Se observó una diferencia significativa entre las categorías profesionales y las variables "edad" ( $p<0,001)$, "uso de medicación" $(p=0,035)$ y "opción por el turno de trabajo" ( $p=0,001)$. Se identificó asociación entre el cronotipo y las variables "alejado del trabajo por motivo 
de enfermedad" ( $p=0,021)$, "hijo $(s)$ " ( $p=0,025)$, “uso de medicación" ( $p=0,018)$ y "turno de trabajo" $(p=0,001)$. Conclusión: Predominó el cronotipo intermedio, y los resultados confirmaron la asociación entre cronotipo y turno de trabajo.

Descriptores: Enfermería; Salud Laboral; Trabajo por Turnos; Ritmo Circadiano; Servicio de Enfermería en Hospital.

\section{CORRESPONDING AUTHOR Rosângela Marion da Silva E-mail: cucasma@terra.com.br}

\section{INTRODUCTION}

Labor market, due to the population's demands, has required that workers operate in shifts, which often does not match their individual preference. Irregular working hours predominate in most countries, with nearly one in four employees working in shifts ${ }^{(1)}$. Workers who perform activities in shifts, in particular those of Nursing, need to consider the best performing hours to execute the activities according to their chronotype.

Chronotype was described as being the different sleepwake cycles $^{(2)}$, an endogenous component of the circadian clock that can play an important role in the ability of a worker to fit to work in shifts ${ }^{(1)}$. It comprises individual trends for choosing the moment to conduct activities during a period with the best state of alert ${ }^{(3)}$. The classification of chronotypes considers individual differences of each worker: morning types - those who prefer to sleep and wake up early, with good state of alert and physical/mental performance for labor activities in the morning; evening types - those who prefer to sleep and wake up late and have good performance for labor activities in the afternoon and early evening; and indifferent - individuals who have greater flexibility and may choose intermediate hours according to the needs of their routine ${ }^{(4)}$.

A survey with nurses in Portugal reinforces this information when it highlights negative correlation between the chronotype and the sleeping and waking hours. Results showed that people with high scores for chronotype (tendency to morningness) show greater willingness to sleep early and wake up early, whereas people with low scores for chronotype (tendency to eveningness) show greater willingness to sleep late and wake up late ${ }^{(5)}$.

From this understanding, researchers report that inadequacy of the nursing worker in relation to chronotype and work shift may result in dissociation of biological rhythms, compromising the occupational performance with the reduction in the level of alertness, vigilance, productivity and affecting social relations and family. Such aspects reinforce the possibility of negative implications on the worker's health and the nursing care in short- and long-term ${ }^{(6)}$.

Although the relationship between the chronotype and the work shift of nursing has been investigated in national ${ }^{(6-8)}$ and international studies ${ }^{(1,5,9-11)}$, the scientific literature on this subject can still be considered incipient ${ }^{(12)}$. In addition, studies that investigate this relation in nursing workers in surgical clinics have not been identified so far.

Thus, in order to contribute to results that could expand the production of knowledge about the chronotype in nursing workers, with special focus on the worker's health, we question: Is there an association between the chronotype and the work shift in nursing workers who work in surgical clinics of university hospitals? To answer this question, our study aimed to identify the predominant chronotype in nursing workers who work in surgical clinics of university hospitals and to verify the association with the work shift.

\section{METHOD}

\section{Ethical aspects}

This study is in line with the ethical recommendations in force in Brazil to conduct research with human beings. The research received a favorable opinion from the Research Ethics Committee on June 29, 2012.

Workers were personally invited and at the job site to participate in the study; they were informed and clarified about the objectives of the research and the willingness to participate. The agreement with the research was expressed by signing the Informed Consent Form in two copies, one for the research coordinator and other for the participant.

\section{Study design, location and period}

Cross-sectional research with a quantitative approach. It was held from July 2012 to January 2013 in surgical clinics of four university hospitals in Southern Brazil, which has a total of six hospitals in this category according to the Ministry of Education.

\section{Sample and inclusion/exclusion criteria}

The study population consisted of 369 nursing workers (95 nurses, 138 nursing technicians and 136 nursing assistants). Criteria for inclusion were: to be a nursing worker, to work with care in the morning shift (7 a.m. -1 p.m.), afternoon (1 p.m. -7 p.m.) or evening (7 p.m. - 7 a.m. of the next day) and to have at least one year of work experience in nursing. Workers who were on leave of any nature and the ones operating in intermediate shifts were excluded from the study.

From these criteria, 16 workers were excluded, and there were five refusals during data collection. The sample size was defined by a specific mathematical formula, which used confidence of $95 \%$, sampling error or maximum margin of error for the proportion of $5 \%$. The sample selection was random, and the application of these parameters produced sample size of 257 nursing workers to ensure the statistical reliability of the study, following the proportionality by occupational category.

\section{Study protocol}

Data collection was performed by four previously trained and certified assistants for this research step to ensure data accuracy.

Participants received two self-fillable instruments. The first one consisted of a questionnaire, prepared by the researchers, with questions related to work and health (age, sex, time of work in surgical clinic, work shift, choice of work shift, children, training to work in the sector, another job, marital status, satisfaction with the job, work leave due to illness in the last year and use of medication). The second was the Morningness-Eveningness Questionnaire ${ }^{(4)}$, Portuguese version, translated and applied to the Brazilian population ${ }^{(13)}$. 
This questionnaire measures self-reported waking and sleep habits. It is composed of 19 questions with multiple choice answers involving the main activities performed by the individual throughout the day, and the answer reflects the preferred hours to perform daily life activities. A score is assigned to each question, and the final score is obtained by the arithmetic sum of each question, and can vary between 16 and 86. The higher the score, the greater the tendency to morningness; and the lower the score, the greater the tendency to eveningness. In this study, to maximize the differences among groups, ratings were reduced from five to three - morning type (59-86 points), intermediate type (42-58 points) and evening type (16-41 points) - as adopted in a preliminary study ${ }^{(1)}$.

\section{Analysis of the results and statistics}

Data were statistically analyzed with the help of the Predictive Analytics Software, SPSS Inc., Chicago - USA), version 15.0 for Windows. Qualitative variables were described by means of the absolute and relative frequency, and associations were held between the chronotype and the variables of the study by using the Chi-square test. When quantitative variables were analyzed, the Kolmogorov-Smirnov test was performed to verify the adherence of data to the normal distribution. Variables "age" and "working time in the unit" did not meet the assumption of normality and were described by means of the median and the interquartile range. The Kruskal-wallis test was used to compare the variables "working time in the unit," "age" and "chronotype," which demonstrated not to be normal in relation to occupational categories. We used the $5 \%$ significance level $(p<0.05)$, and reliability was evaluated by means of the Cronbach's alpha coefficient.

\section{RESULTS}

The sample consisted of all eligible workers who agreed to participate in the study, composing a final quantitative of 270 workers (65 nurses, 110 nursing technicians and 95 nursing assistants). In Table 1, we displayed the socio-occupational variables of nursing workers in surgical clinics.

We found association between the position of a nursing assistant and the variables "use of medication" $(p=0.035)$ and "choice of work shift" $(p=0.001)$.

It was observed that the people surveyed were around 40 years old. Among the nursing assistants, the age was around 46 (minimum, 33; and maximum 60); among the nursing technicians, 35 (minimum, 20; and maximum, 68); and among the nurses, 40 (minimum, 24; and maximum, 62). It was noted by the Kruskall-Wallis test, supplemented by the Multiple Comparisons test, that the variable "age" significantly differed among occupational categories $(p<0.001)$. Nursing assistants were the workers with older age in relation to nursing technicians and nurses (Median =46).

It was observed that the working time in surgical clinic was around eight years. The occupational category of the nursing assistants was acting in the field longer, around 10 years (minimum, 1 ; and maximum, 30), followed by nurses with working time of seven years (minimum, 0; and maximum, 26), and nursing technicians, three years of experience in the unit (minimum, 0 ; and maximum, 37). In this variable, no statistically significant difference was found in the occupational categories $(p=0.098)$.

Table 1 - Socio-occupational variables of nursing workers in surgical clinics, Rio Grande do Sul, Brazil, 2014

\begin{tabular}{|c|c|c|}
\hline Socio-occupational variables & $\mathbf{n}$ & $\%$ \\
\hline \multicolumn{3}{|l|}{ Sex } \\
\hline Female & 222 & 82.22 \\
\hline Male & 48 & 17.78 \\
\hline \multicolumn{3}{|l|}{ Children } \\
\hline Yes & 190 & 70.37 \\
\hline No & 80 & 29.63 \\
\hline \multicolumn{3}{|l|}{ Spouse } \\
\hline Yes & 159 & 58.89 \\
\hline No & 111 & 41.11 \\
\hline \multicolumn{3}{|l|}{ Satisfaction with the job } \\
\hline Yes & 253 & 93.70 \\
\hline No & 17 & 6.30 \\
\hline \multicolumn{3}{|l|}{ Use of medication* } \\
\hline Yes & 107 & 39.63 \\
\hline No & 163 & 60.37 \\
\hline \multicolumn{3}{|l|}{ Work shift } \\
\hline Morning & 78 & 28.88 \\
\hline Afternoon & 72 & 26.67 \\
\hline Night & 120 & 44.45 \\
\hline \multicolumn{3}{|l|}{ Training } \\
\hline Yes & 194 & 71.85 \\
\hline No & 76 & 28.15 \\
\hline \multicolumn{3}{|l|}{ Other job } \\
\hline Yes & 50 & 18.52 \\
\hline No & 220 & 81.48 \\
\hline \multicolumn{3}{|l|}{ Work leave } \\
\hline Yes & 60 & 22.22 \\
\hline No & 210 & 77.78 \\
\hline \multicolumn{3}{|l|}{ Choice of shift* } \\
\hline Yes & 220 & 81.48 \\
\hline No & 50 & 18.52 \\
\hline
\end{tabular}

Note: ${ }^{*} p<0.05$

The chronotype questionnaire presented satisfactory internal consistency (Cronbach's alpha $=0.82$ ). Workers with indifferent chronotype were predominant $(45.20 \%, \mathrm{n}=122)$. There was no association between the chronotype and the occupational categories $(p=0.059)$. Figure 1 presents the chronotype distribution according to the occupational category of nursing workers in surgical clinics.
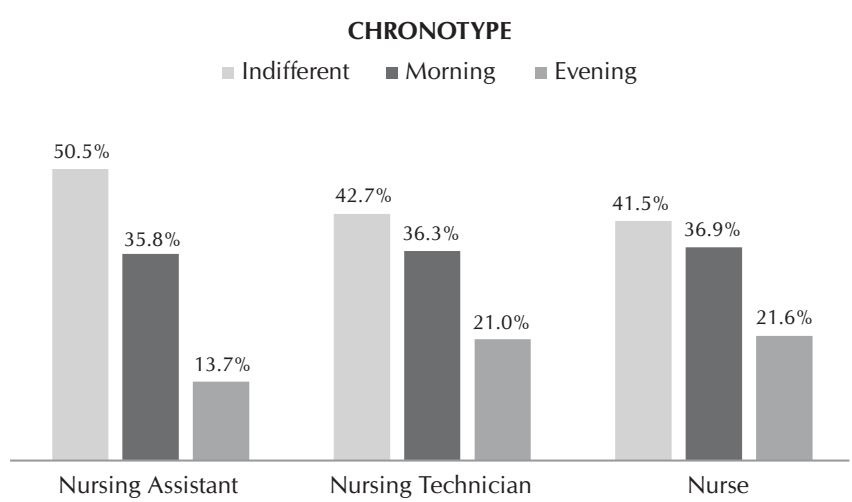

Figure 1 - Chronotype distribution according to the occupational category of nursing workers in surgical clinics, 2014 
Regarding age, it was found that workers with morning chronotype were, on average, older than the indifferent and evening chronotypes (Median=43). Regarding the time of work in the unit, it was observed that those with evening chronotype have been in the unit less time in relation to participants with indifferent and morning chronotypes. No association was identified among the chronotype and the variables "age" and "time of work in unity" ( $p>0.05$ ).

There was an association between the morning chronotype and the variable "children" $(p=0.025)$, indifferent chronotype in the variable "use of medication" ( $p=0.018)$, morning and afternoon chronotypes in the variable "work leave due to illness" $(p=0.021)$, and morning chronotype and "work shift" $(p=0.001)$. Figure 2 presents the variable "work shift" according to the chronotype.

\section{CHRONOTYPE AND WORK SHIFT}

- Indifferent $\square$ Morning Evening

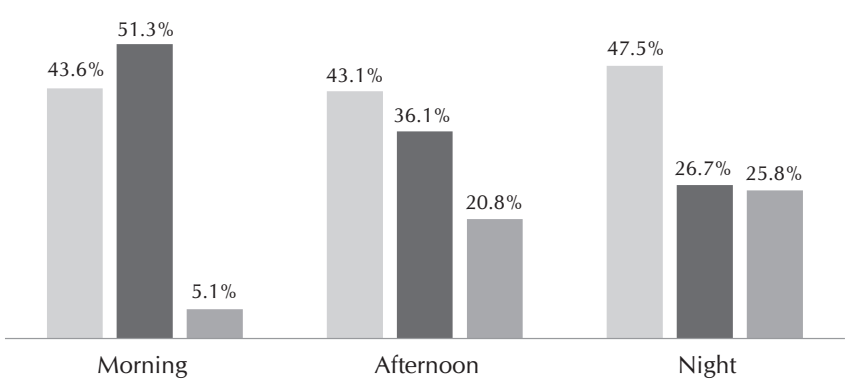

Figure 2 - Chronotype distribution of nursing workers who work in surgical clinic according to the work shift, 2014

\section{DISCUSSION}

About the results, we point out that the age around 40 years old suggests certain life experience, which can be favorable in the awareness of workers to care for their health and the possible implications of the working environment in their lives.

Regarding work shift, it was found that the largest portion of participants worked on the night shift. About this, we mention: workers who carry out labor activities at night need to sleep during the day, but their circadian rhythms do not reverse, because despite having their working hours inverted, this does not occur with their social and family lives. This causes the body to have the feeling of being exposed to a conflict, because insufficient sleep negatively interferes in the daytime activities, predisposing the individual to low efficiency and risk of accidents ${ }^{(14)}$.

There was a prevalence of participants with only one employment relationship, which suggests positive impact on health, quality of life and social coexistence. Thus, the study states that, when there is a double employment relationship, the worker is subject to higher incidence of accidents when performing labor activities and to lower possibility of relationships due to the accelerated pace of work, which has a negative repercussions in terms of performance, physical and mental health ${ }^{(15)}$.
However, it is pertinent to consider that some workers have another job. In this context, it should be noted: the functioning of hospital organization requires a regime of shifts, which allows the double employment relationship and the long days of work, practices developed as a way to supplement the income and that contribute to the excessive workload $^{(16)}$, and may result in work leave because of worker's illness.

The hospital context offers many situations that submit the nursing workers to various workloads, which can be manifested abruptly as in the example of work accidents or of gradual exponential to wear and diseases ${ }^{(17)}$. Such aspects refer to the need to consider the overlapping of such risks in the case of double employment and/or overload of activities. In addition, it is worth mentioning the restriction of rest and leisure hours, which may result in health impairment and need for work leave because of illness.

A study in a hemodialysis service identified that nurses who were on work leave and had another job, when compared with nursing technicians and assistants ${ }^{(18)}$, evaluated relationships at work more positively, i.e., for nurses in this condition, such relationships are pleasant and an aspect to be kept in the working environment.

In our study, we identified association of variable "use of medication" and the category "nursing assistant" $(p=0.035)$, which may be associated with the "age" factor, since these individuals were older when compared with nursing technicians and nurses.

This occupational category was also the one that most chose the work shift $(p=0.001)$. This choice can be a factor of job satisfaction because it refers to the possibility of reconciliation between the performance of labor activities and personal interests of the workers such as the care of their children and the professional qualification.

The prevalent chronotype among participants was the indifferent $(45.2 \%, n=122)$, convergent with data from research conducted with Spanish nurses ${ }^{(10)}$, Iranian nurses ${ }^{(1)}$ and in a study conducted with Portuguese nurses ${ }^{(5)}$, a fact that suggests these workers may have the ability to adjust their hours according to their work routines $^{(5)}$. The indifferent chronotype absorbs characteristics of the morning and evening chronotypes, without a specific preference for sleeping and waking hours.

This result diverges from a study carried out on nurses in the region of Vale do Paraíba Paulista, São Paulo, Brazil ${ }^{(7)}$ and a study on Dutch nurses ${ }^{(11)}$. In such research, there was prevalence of moderately morning and morning chronotypes, respectively.

When we associated age with chronotype, the highest average age was observed among workers with morning chronotype, similar to the data found in a Spanish study ${ }^{(10)}$. This result reinforces the evidence that individuals tend to become morning people as the years go by, willing to advance the phase of their biological rhythms, opposite trend found at puberty ${ }^{(19)}$.

Another association found was evidenced with the variable "children" and the chronotype, because workers with children were associated with the morning chronotype $(p=0.025)$. A study suggests that women with children tend to morningness, which may be related to social demands of children's education $^{(20)}$. This result converges with the one found in a survey with intensive care nurses, which identified that the morning chronotype was more likely to have children aged less than 12 
years old. In this age group, children are usually dependent on their parents for supervision and school transport; this indicates that age limits the ability to sleep in preferred hours ${ }^{(11)}$.

Significant differences were evidenced between the indifferent chronotype and the variable "use of medication" $(p=0.018)$; and the morning chronotype and the "no use of medication." Regarding this aspect, a research conducted on nursing workers in Oncology intensive care unit identified that self-medication seems to be a common and accepted practice in hospitals due to the easy access to medicines and knowledge of professionals about their effects, which suggests the possibility of risk to health and illness of these people $e^{(21)}$.

There was a significant association among workers who had a work leave due to illness and the evening chronotype $(p=0.021)$; and among the participants without work leave and morning chronotype. It should be noted that a significant portion of morning chronotype workers was working on the day shift, thus, consistent with work shift and chronotype. However, we identified evening chronotype workers working in the day shift, a fact that suggests disagreement.

These data need to be considered in the context of workers' health, since this disharmony may result in quality impairment of the care provided. Research on nursing workers found $70.58 \%$ of respondents had disagreement between the chronotype and the work shift ${ }^{(8)}$. Another study identified statistical significance between chronotype and work shift in 388 American Nurses; the morning chronotype was more adaptated to the day shift and less to the night shift, while the evening chronotype presented intermediate levels of adaptation to the day and night shift ${ }^{(9)}$. Studies reinforce that the morning chronotype seems to have more difficulties of adaptation related to the work in shifts than the evening chronotype ${ }^{(1)}$.

From this perspective, it is necessary to consider, in addition to the personal characteristics of workers, the environment, the work organization in shifts and the process of nursing work, because these elements can enhance or cause disorders in different spheres of the worker's life. It is advisable, in this regard, to identify chronotypes individually; obtaining and using this information is a differential in health organizations, because it enables to adjust the work shift with the individual tendency, which may favor health assistance, prevention of accidents and damages to the workers' health.

In terms of the nursing workers' health, one of the negative consequences of this desynchronization is physical and psychological wear, arising from lack of work process organization and unpreparedness to deal with people suffering with health needs. The negative repercussions of work environment on the workers' health may reflect on the effectiveness of their work process, feeding a vicious cycle in which the worker and the care production process remain in constant disharmony. In addition, this situation exposes the patient - object of the nursing work - to an impaired and ineffective quality of care $^{(22)}$.

When analyzing the labor relationships in shifts with the characteristics of the nursing workers and the possible reflections of these relationships in their quality of life and health, it is necessary to consider age, chronotype, adaptability capacity, working hours' duration and aspects related to the conditions that influence the workplace. The analysis of these elements can assist in the planning of actions in favor of the health of workers in shifts, minimizing consequences and enhancing the quality of life.

Thus, this study contributed to enlarge the production of knowledge about chronotype in nursing workers. Further studies are needed in order to plan interventions that offer workers opportunities to recognize themselves as co-responsible for maintaining their health. This will allow the participation in the choice of shift that best favors their professional and personal performance according to their chronotype.

Thus, although there is a predominance of workers who are not on leave of their labor activities due to illness in the investigated sample, workers on leave should be considered. We suggest to conduct a detailed study about the work leaves along with the Occupational Health Services of the institutions surveyed, because this information may offer subsidies to identify resources that could be used to offer workers an environment that cares about their health, job satisfaction and, consequently, that contributes to the reduction of the number of work leaves.

\section{Study limitations}

The limitations of this study are related to the cross-sectional design, since the reverse causality cannot be ruled out. Another limitation is that it was held in a given sample of nursing workers in the Southern region of Brazil. Therefore, generalizations should be made with care and be circumscribed to the sample of the investigated population.

\section{Contributions to the nursing field}

This study advances in the construction of knowledge in the field of nursing and health care regarding the chronotype in nursing workers in surgical clinic. It is expected that the results may contribute to raise and support measures aimed at health promotion and disease prevention of nursing workers.

\section{CONCLUSION}

The predominant chronotype in nursing workers in surgical clinics of Rio Grande do Sul was the indifferent type. Results confirmed the association between chronotype and work shift $(p=0.001)$. In addition, associations were identified between the chronotype and the variables "work leave due to illness" $(p=0.021)$, "children" $(p=0.025)$ and "use of medication" $(p=0.018)$.

In this perspective, we need to consider: workers who develop their occupational activities in a shift that is divergent from their chronotype may experience changes in health, which may also have implications in the quality of care provided in the health services.

\section{FUNDING}

We thank the National Science and Technology Council (CNPQ), Process 14/2011 no. 476041/2011-2, and the Scientific Initiation Program of Hospital Universitário de Santa Maria (PROIC-HUSM) for the financial aid for this research. 


\section{REFERENCES}

1. Yazdi Z, Sadeghniiat-Haghighi K, Javadi AR, Rikhtegar G. Sleep quality and insomnia in nurses with different circadian chronotypes: morningness and eveningness orientation. Work[Internet]. 2014[cited 2016 May 05];47(4):561-7. Available from: https:// www.ncbi.nlm.nih.gov/pubmed/23823210

2. Argent AC, Benbenishty], Flaatten H. Chronotypes, night shifts and intensive care. Intensive Care Med[Internet]. 2015 [cited 2016 May 05];41(4):698-700. Available from: https://dx.doi.org/10.1007/s00134-015-3711-7

3. Urbán R, Magyaródi T, Rigó A. Morningness-eveningness chronotypes and health-impairing behaviors in adolescents. Chronobiol Int[Internet]. 2011[cited 2016 Nov 10];28(3):238-47.Available from: https://www.ncbi.nlm.nih.gov/pmc/articles/PMC3818690/.

4. Horne JA, Ostberg O. A self-assessment questionnaire to determine morningness-eveningness in human circadian rhythms. Int J Chronobiol. 1976;4(2):97-110.

5. De Martino MMF, Abreu ACB, Barbosa MFS, Teixeira JEM. The relationship between shift work and sleep patterns in nurses. Ciênc Saúde Colet [Internet]. 2013 [cited 2016 Nov 10];18(3):763-68. Available from: http://www.scielo.br/pdf/csc/v18n3/22.pdf

6. Xavier KGS, Vaghetti HH. Aspectos cronobiológicos do sono de enfermeiras de um hospital universitário. Rev Bras Enferm [Internet]. 2012[cited 2016 Nov 10];65(1):135-40. Available from: http://www.scielo.br/pdf/reben/v65n1/20.pdf

7. Santos TCMM, Inocente NJ, De Martino MMF. Work shifts: chronotype relations and quality sleep. Rev Enferm UFPE [Internet]. 2014[cited 2016 Nov 10];8(10):3437-43. Available from: http://www.revista.ufpe.br/revistaenfermagem/index.php/revista/article/ view/5154/pdf_6287

8. Souza SBC, Tavares JP, Macedo ABT, Moreira PW, Lautert L. Influence of work shift and chronotype on the quality of life of nursing professionals. Rev Gaúch Enferm[Internet]. 2012[cited 2016 Nov 10];33(4):79-85. Available from: http://www.scielo.br/pdf/ rgenf/v33n4/en_10.pdf

9. Gamble KL, Motsinger-Reif AA, Hida A, Borsetti HM, Servick SV, Ciarleglio CM, et al. Shift work in nurses: contribution of phenotypes and genotypes to adaptation. PLoS One[Internet]. 2011 [cited 2016 May 05];6(4):e18395. Available from: https://dx.doi. org/10.1371/journal.pone.0018395

10. Martíneza MR, Casbas TM, Pinto AS,González-María E, Reina MH, Fernández AO. Chronotype and daytime sleepiness in nurses working in six hospitals of the Spanish National Health System. Abstracts/Sleep Medicine [Internet]. 2013 [cited 2016 Nov 10]; 14S:239-317.DOI: http://dx.doi.org/10.1016/j.sleep.2013.11.610

11. Reinke L, Özbay Y, Dieperink W, Tulleken JE. The effect of chronotype on sleepiness, fatigue, and psychomotor vigilance of ICU nurses during the night shift. Intensive Care Med[Internet]. 2015 [cited 2016 May 05];41(4):657-66. https://dx.doi.org/10.1007/ s00134-015-3667-7

12. Silva RM, Zeitoune RCG, Beck CLC, Loro MM. Matutino, vespertino ou indiferente? Produção do conhecimento sobre o cronotipo na enfermagem. Rev Enferm UFSM [Internet]. 2014 [cited 2016 Nov 10];4(4):835-43. Available from: https://periodicos.ufsm. $\mathrm{br} /$ reufsm/article/view/12888/pdf

13. Benedito-Silva AA, Menna-Barreto L, Tenreiro S. Self-assessment questionnaire for the determination of morningness-eveningness types in Brazil. Prog Clin Biol Res. 1990; 314: 89-98.

14. Ferreira LRC, Miguel MAL, De Martino MMF, Menna-Barreto L. Circadian rhythm of wrist temperature and night shift work. Biol Rhythm Res[Internet]. 2013[cited 2016 May 05];44(5):737-44. Available from: http://dx.doi.org/10.1080/09291016.2012.739931

15. Mininel VA, Baptista PCP, Felli VEA. Psychic workloads and strain processes in nursing workers of brazilian university hospitals. Rev Latino-Am Enfermagem [Internet]. 2011[cited 2016 Nov 10];19(2):340-7. Available from: http://www.scielo.br/pdf/rlae/ v19n2/16.pdf

16. Monteiro JK, Oliveira ALL, Ribeiro CS, Grisa GH, Agostini N. Adoecimento psíquico de trabalhadores de unidades de terapia intensiva. Psicol Cienc Prof [Internet]. 2013[cited 2016 Nov 10];33(2):366-79. Available from: http://www.scielo.br/pdf/pcp/ v33n2/v33n2a09.pdf

17. Mininel VA, Felli VEA, Silva EJ, Torri Z, Abreu AP, Branco MAT. Workloads, strain processes and sickness absenteeism in nursing. Rev Latino-Am Enfermagem[Internet]. 2013[cited 2016 Nov 10];21(6):1290-97. Available from: http://www.scielo.br/pdf/rlae/ v21n6/0104-1169-rlae-21-06-01290.pdf

18. Prestes FC, Beck CLC, Magnago TSBS, Silva RM, Tavares JP. Working context in a hemodialysis service: evaluation of nursing staff. Texto Contexto Enferm[Internet].2015[cited 2016 Nov 10];24(3):637-45. Available from: http://www.scielo.br/pdf/tce/ v24n3/0104-0707-tce-24-03-00637.pdf

19. Monk TH, Kupfer DJ. Which aspects of morningness-eveningness change with age? J Biol Rhythms[Internet]. 2007[cited 2016 May 05];22(3):278-80. Available from: https://dx.doi.org/10.1177/0748730407301054

20. Leonhard C, Randler C. In sync with the family: children and partners influence the sleep-wake circadian rhythm and social habits of women. Chronobiol Int. 2009; 26(3):510-25.

21. Oliveira AF, Teixeira ER. Conception about self-medication use by the nursing staff in oncology intensive care. Rev Enferm 
UFPE [Internet]. 2016 [cited 2016 Dec 09];10(1):24-31. Available from: http://www.revista.ufpe.br/revistaenfermagem/index.php/ revista/article/view/8463/pdf_9307

22. Portella Ribeiro J, Pereira Rocha L, Demutti Pimpão F, Rutz Porto A, Buss Thofehrn M. Implicaciones del ambiente en el desarrollo del proceso de trabajo de enfermería: una revisión integradora. Enferm Global [Internet]. 2012[cited 2016 Nov 10];27:379-87. Available from: http://revistas.um.es/eglobal/article/view/147871/136461 